\title{
Effect of the vitamin D photosynthesis products on thermodynamic parameters of model lipid membranes
}

\author{
N. A. Kasian, O. V. Vashchenko, Ya. E. Gluhova ${ }^{1}$, L. N. Lisetski \\ Institute for scintillation materials, STC «Institute for Single Crystals», NAS of Ukraine \\ 60, Lenin ave., Kharkiv, Ukraine, 61001 \\ ${ }^{1}$ V. N. Karazin Kharkiv National University \\ 4, Svobody Sq., Kharkiv, Ukraine, 61077 \\ kasian@isma.kharkov.ua
}

\begin{abstract}
Aim. To compare effects of vitamin D (VitD), provitamin D (ProD) and its photo- and thermoisomerization products on thermodynamical pa-rameters of hydrated dipalmitoylphoshpatidylcholine (DPPC) multi-layers. Methods. Differential scanning calorimetry, UV spectroscopy. Results. A regular decrease was established in the melting temperatu-re accompanied with the pronounced broadening of the appropriate pe-aks for DPPC multilayers doped with the sterols in the order ProD $<<P_{3} D_{3}+U V<P_{r o D}+U V+$ dark storage $<$ VitD ${ }_{3}$. Conclusions. The destabilizing effect of Vit $D_{3}$ on the membrane appeared to be stron- ger than that of ProD $D_{3}$ and its photoisomerization products. This can fa-cilitate VitD $D_{3}$ withdrawal from the membrane into intercellular space under its biosinthesis in vivo. A possible molecular mechanism of the phenomena observed is related to the higher conformational flexibility and anisometry of $V$ it $D_{3}$ as compared to $P_{r o D_{3}}$
\end{abstract}

Keywords: phospholipid membranes, vitamin D, provitamin D, photoisomerization, differential scanning calorimetry.

Introduction. The biosynthesis of vitamin D (VitD) from provitamin D (ProD) in humans and animals is known to occur in the epidermal cell membranes under the effect of UV-radiation [1]. This reaction, currently considered to be well-studied, includes both light and dark stages [2-4]. At the first stage of the isomerization an intermediate product - previtamin D - is formed from ProD with subsequent transformation into more stable photoisomers (tachysterol and lumisterol) or back into ProD. The formation of VitD from previtamin $\mathrm{D}$ is performed at the dark stage due to the intramolecular transfer of hydrogen (Fig. 1) [2-4]. The dependence of photochemistry of this process on the spectral characteristics of UV radiation is well-known [4-8], however, the reaction medium is also of significant impact.

As stated above, the synthesis of VitD in vivo occurs in the cellular membrane, the structural and

(C) Institute of Molecular Biology and Genetics, NAS of Ukraine, 2012 functional basis of which is the lipid layer, thus, a number of works [9-13] present a comparative study on this process in skin, model lipid membranes and isotropic solvents. Similarities of photoisomerization in skin and liposomes were demonstrated, as well as significant differences compared to isotropic organic solvents $[9,10]$. Thus, it was observed that at the light stage the isotropic solvent promotes the accumulation of tachysterol (trans-conformation of C5-C6 bond) while liposomes promote the same for ProD, previtamin D and lumisterol (cis-conformation of C5-C6 bond) [10, 11]. The rate of dark "previtamin D $\rightarrow$ VitD" transformation in liposomes and in skin is 10-15 times higher than that in isotropic solvents, while the activation energy is decreased [9-13].

Besides, in other anisotropic media - cholesteric [14] and nematic [15] liquid crystals, heterogeneous systems $[16,17]$ - differences were also observed between the processes of photo- and thermoisomerization of ProD compared to isotropic solvents. 


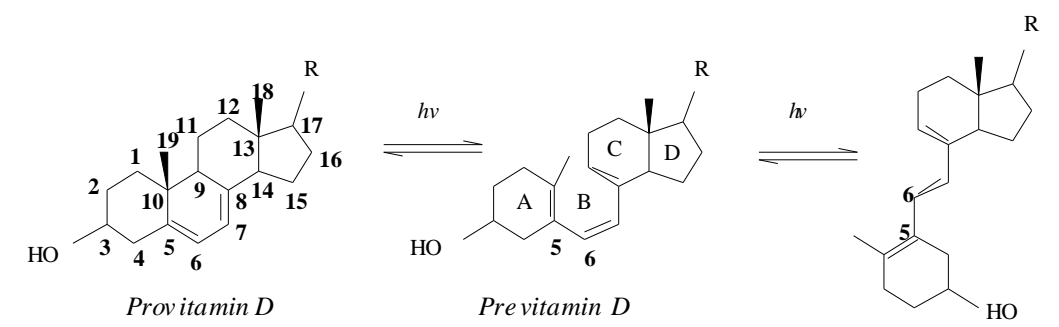

Tachysterol

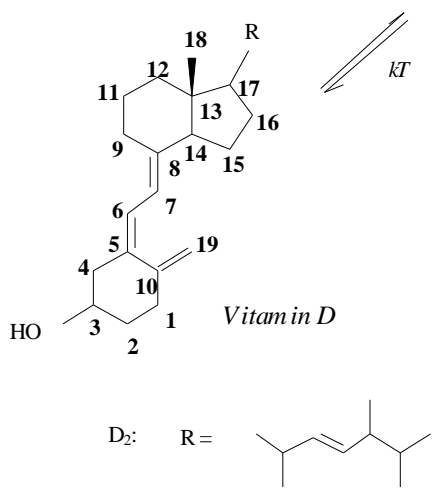

In some works these effects are related to spatial constraints of anisotropic environment on conformationally flexible previtamin $\mathrm{D}$ which stabilizes the latter in the form with cis-conformation of C5-C6 bond - the only bond, the participation of which enables the formation of VitD [9-13]. It is confirmed by the presence of positive correlation between the forces of anisotropic amphiphilic interaction between lipids and previtamin D (defined by the length and saturation degree of carbohydrate chains of phospholipids) and the rate of isomerization of "previtamin D $\rightarrow$ VitD" [9]. Besides, high yield of VitD in vivo may also be explained by the release of already formed VitD from the cellular membrane that shifts the reaction "previtamin D $\rightarrow$ VitD" balance towards VitD (i.e. the thermoisomerization reaction becomes irreversible and the true thermodynamic equilibrium is never reached in this reaction) [1, 11]. Therefore, the lipid bilayer, serving as a reaction medium, presupposes high efficiency of VitD synthesis in vivo, due to which the works $[9,10]$ suggest using it as a model medium for the study of VitD synthesis.

The authors $[9,10,18]$ suggested a model of ProD localization in the phospholipid membrane: the non-polar part of the sterol molecule is located in the hydrophobic area of the membrane; it interacts with carbohydrate lipid tails, the hydroxyl group is directed towards the carbonyl group of one of the lipid chains with possible formation of H-bond [19]. From the extracellular space VitD penetrates into the bloodstream, where it is transported via the special vitamin D-binding protein [1]; however, the mechanism of VitD desorption from the lipid membrane is yet to be established.

The membranotropic activity of VitD was investigated in a number of works [19-26], but the current data on its impact on the temperature of the main phase transition of $\mathrm{Tm}$ bilayer (membrane melting) are contradictory. It was observed that VitD2 in the concentration of $1 \mathrm{~mol} \%$ increases $\operatorname{Tm}[22,23]$ while other works demonstrate that in small concentrations $(1 \div 6 \mathrm{~mol} \%)$ VitD2 does not have any effect [19,24], and in large concentrations $(9 \div 12 \mathrm{~mol}$ $\%$ ) it lowers $\mathrm{Tm}$ by several degrees and decreases the transition enthalpy $[19,21,24-26]$. The analysis of the characteristic bands of IR-vibrations of different groups of phospholipid allowed determining that in small concentrations VitD causes the ordering of alkyl lipid tails ( a decrease in mobility and number of gauche conformers), while in large concentrations it induces the disordering of hydrophobic area of the membrane $[19,22]$. There was a notable decrease in the order 
parameter [20] and an increase in the fluidity of VitD enriched membranes.

The membranotropic impact was not studied for ProD contrary to VitD. Besides, there are no studies on the impact of the ProD isomerization process on the structure of lipid membranes. At the same time the determination of membranotropic constituent of the VitD biosynthesis process may deepen understanding the mechanism of its biological impact at the molecular level. Therefore, the aim of this work is the comparison of the impact of ProD, the products of its photoisomerization and VitD on the thermodynamic parameters of the model lipid membrane on the basis of bilayer structures of the hydrated dipalmitoylphosphatidylcholine (DPPC).

Materials and Methods. Water dispersions of DPPC (Alexis Biochemicals, Switzerland) were used as model lipids of the membranes. As additives, we used sterols present in the human organism: 7-dehydrocholesterol $\left(\mathrm{ProD}_{3}\right)$ and cholecalciferol $\left(\mathrm{VitD}_{3}\right)$ (Sigma-Aldrich, USA).

The selection of the concentration of sterols is conditioned by the requirement of system homogeneity (the absence of phase separation [19]), on the one hand, and the necessity of obtaining clearly registered and reproducible changes, on the other. The experimentally selected optimal concentration of the additive, meeting these two conditions, is $7 \% \mathrm{wt}$ relative to dry DPPC, which corresponds to the DPPC:sterol ratio of 7:1.

The method of preparing DPPC water dispersions with additives is as follows. Phospholipid and sterol in the required mass ratio are located into the roundbottom flask and dissolved in chloroform, with the solvent subsequently pumped off using a rotary evaporator. As a result, a thin homogeneous precipitated layer of the multicomponent mixture is deposited on the walls of the flask lower part. Distilled water is added in the ratio of $\sim 75 \%$ wt. This amount of water secures the system existence in the lamellar phase upon changes in humidity $\pm 20 \%$. The system is kept at room temperature for 2-3 days with periodic heating on the water bath to the temperature of $\sim 50^{\circ} \mathrm{C}$ (i.e. to $\mathrm{T}>\mathrm{Tm}$ ) with intense stirring.

The systems were studied by the differential scanning calorimetry (DSC) using a Mettler TA 3000 thermoanalytical system (Switzerland). The phase tran- sitions from the low temperature (gel) phase $\mathrm{L}_{\beta}$, into the intermediary $\mathrm{P}_{\beta}$, phase (pre-transition) and then to the high temperature (liquid crystal) $\mathrm{L}_{\alpha}$ phase (the main transition or membrane melting) were studied [27, 28]. The investigated samples of $20-30 \mathrm{mg}$ were placed into aluminum crucibles and sealed. The programmed scheme of the temperature scanning consisted of consecutive cycles of heating and cooling with the rate of $2 \mathrm{~K} / \mathrm{min}$. The parameters of the phase transitions were determined on the basis of the obtained thermograms using the corresponding software. The size of the cooperative $\mathrm{N}$ domain was calculated according to [29] using the formula

$$
N=\Delta H_{\text {вг }} / \Delta H_{m} \approx 7 T_{m}^{2} / \Delta T_{1 / 2} \cdot \Delta H_{m},
$$

where $\Delta \mathrm{HVH}$-Vant Hoff enthalpy; Tm, $\Delta \mathrm{Hm}$ and $\Delta \mathrm{T} 1 / 2$ - temperature, enthalpy and half-width of the main transition peak, respectively.

UV absorption spectra of the investigated systems were obtained using a Hitachi 330 spectrophotometer (Japan) at room temperature. The sample was placed between quartz glasses, the sample thickness was 3-5 $\mu \mathrm{m}$.

The samples were irradiated by the illuminator on the basis of mercury quartz lamp DRT-240 with the known distribution of spectral irradiance [30] at the distance of $25 \mathrm{~cm}$. The exposure time was $10 \mathrm{~min}$, which corresponds to the dose of UV-radiation of 1.4 Joule/sq.cm. (UV-B and UV-C are 0.9 Joule/sq.cm in total).

Results and Discussion. The multilayer structures of hydrated DPPC were used to compare the effect of sterols $\mathrm{ProD}_{3}$ and $\mathrm{VitD}_{3}$, as well as the products of photo- and thermoisomerization of $\mathrm{ProD}_{3}$, on the features of the lipid component of biomembranes. At the selected level of hydration ( $75 \% \mathrm{wt}$ ) these structures are practically independent bilayers divided by interlayers of free water, which allows direct application of the obtained results to the bilayer. Here the variance of water content in the range of $\pm 10 \div 20 \%$ does not have any effect on the phase state of water dispersion of DPPC and the temperature of phase transitions [27, 29].

For all the investigated systems DSC-thermograms were obtained in the coordinates of "heat flow temperature" in the modes of heating (Fig. 2, a) and 

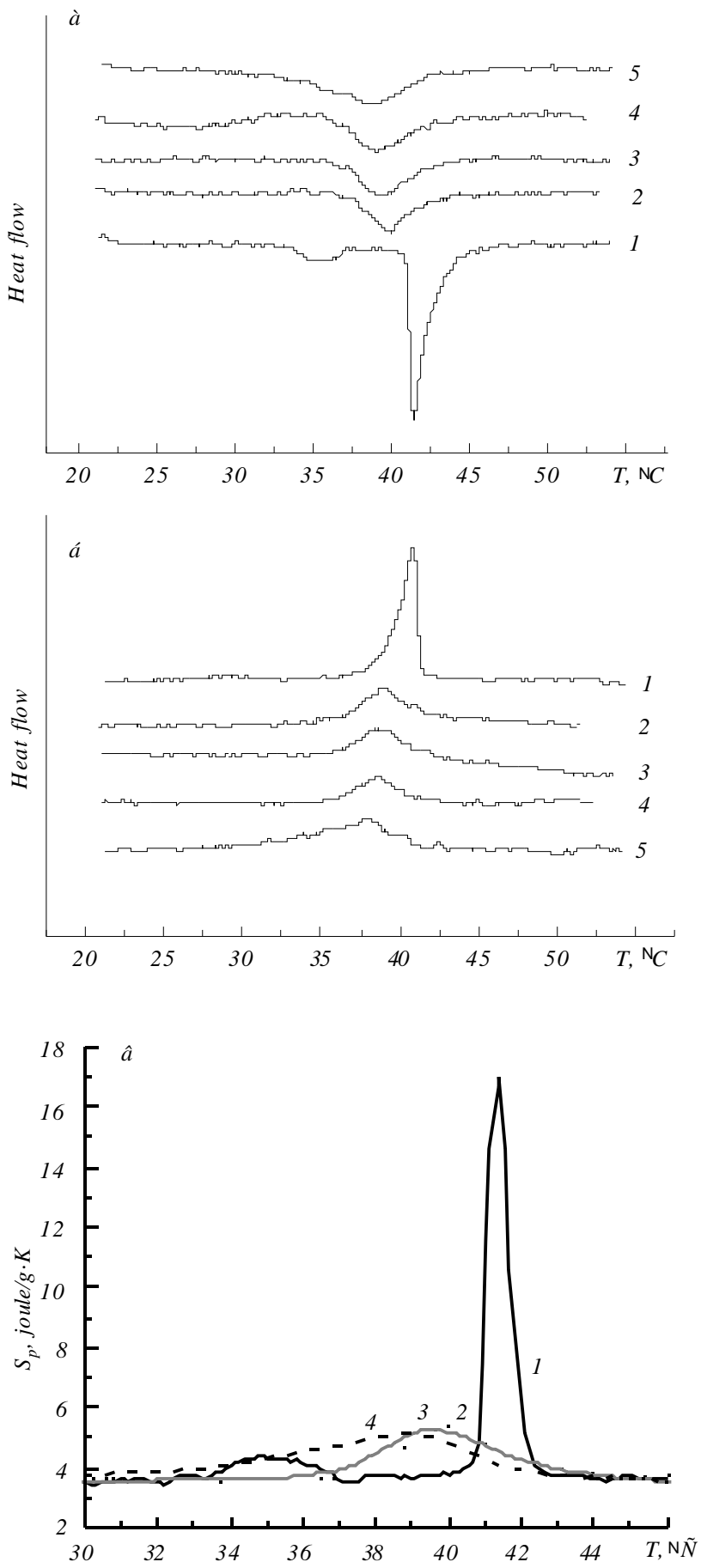

Fig. 2. The thermograms of water dispersions of dipalmitoylphosphatidylcholine, obtained by the method of differential scanning calorimetry: $a$-in the heating mode; $b$ - in the cooling mode $\left(1-\right.$ without additives; $2-\operatorname{ProD}_{3} ; 3-\operatorname{ProD}_{3}+\mathrm{UV} ; 4-$ ProD $_{3}+\mathrm{UV}+$ dark storage $\left.5-\mathrm{VitD}_{3}\right) ; c$ - temperature dependence of the specific heat capacity of these systems $(1-$ without additives; 2 $\operatorname{ProD}_{3} ; 3-\mathrm{ProD}_{3}+\mathrm{UV} ; 4-\mathrm{VitD}_{3}$ ) cooling (Fig. 2,b), with subsequent calculation of the temperature dependencies of specific heat (Fig. 2,c). The Table presents thermodynamic parameters of the main phase transition of the model lipid membranes with different additives: temperature $\left(\mathrm{T}_{\mathrm{m}}\right)$, enthalpy $\left(\Delta \mathrm{H}_{\mathrm{m}}\right)$, half-width of the melting peak $\left(\Delta \mathrm{T}_{1 / 2}\right)$, hysteresis, the size of cooperative domain $(\mathrm{N})$ as well as the shift of melting temperature at the introduction of additive (in the heating mode) $\Delta \mathrm{T}_{\mathrm{m}}=\mathrm{T}_{\mathrm{m}}$ (DPPC + additive) $-\mathrm{T}_{\mathrm{m}}$ (DPPC). The Student's method was used to determine the confidence interval for the reliability $\mathrm{p}$ $=0.95$ for direct measurements with the number of degrees of freedom $\mathrm{f}=5$.

Two phase transitions - pretransition $\left(\mathrm{T}_{\mathrm{p}}=35.5^{\circ} \mathrm{C}\right)$ and a more intense main phase transition $\left(\mathrm{T}_{\mathrm{m}}=41.4\right.$ ${ }^{\circ} \mathrm{C}$ ), reproducible in the consecutive cycles of heating and cooling, are evident on the DSC-thermograms of pure DPPC during heating. The phase transition temperatures are in good agreement with the literature data $[27,28]$. The pretransition becomes obscure up to disappearing in the cooling mode, the hysteresis of 0.6 ${ }^{\circ} \mathrm{C}$ is observed for the main phase transition. The pretransition peak vanishes in the presence of additives, while the main transition shifts towards lower temperatures and is blurred, which indicates the disorder of the lipid bilayer. There are no significant changes in the hysteresis.

Let us consider in more detail the differences in the effect of the additives. The introduction of $\mathrm{ProD}_{3}$ leads to the decrease in $\mathrm{Tm}$ by $1.5^{\circ} \mathrm{C}$ relative to the initial system of pure DPPC in the heating mode and by $1.9^{\circ} \mathrm{C}$ - in the cooling mode. The UV-irradiation of this system results in further decrease in the membrane melting temperature (by $0.5^{\circ} \mathrm{C}$ more). The change in the temperature of the membrane main phase transition Tm during UV-radiation is likely to be related to the occurrence of $\mathrm{ProD}_{3}$ photoisomers in the system (Fig. 1). This is confirmed by the changes in the UV-spectrum of the system absorption (Fig. 3) with the observed increase in the optical density, which is characteristic for the occurrence of tachysterol photoisomer [3, 4]. The dark storage of the irradiated sample for 24 hours resulted in further decrease in Tm (by $0.4^{\circ} \mathrm{C}$ in the heating mode), accompanied by the increase in optical density at the wavelength of $265 \mathrm{~nm}$ (Fig. 3, curve 5), indicating the formation of $\mathrm{VitD}_{3}$ [4]. 
The impact of sterol additives on the thermodynamic characteristics of the main phase transition of the model lipid membrane on the basis of water dispersions of dipalmitoylphosphatidylcholine

\begin{tabular}{|c|c|c|c|c|c|c|c|c|}
\hline Additive & \multicolumn{3}{|c|}{ Heating } & \multicolumn{2}{|c|}{ Cooling } & Hysteresis, ${ }^{\circ} \mathrm{C}$ & $N$ & $\Delta T_{m}$ \\
\hline Without additives & $41,4 \pm 0,1$ & $25,0 \pm 1,8$ & $1,1 \pm 0,2$ & $40,8 \pm 0,1$ & $12,8 \pm 1,7$ & $0,6 \pm 0,2$ & $151 \pm 39$ & - \\
\hline ProD $_{3}$ & $39,9 \pm 0,1$ & $15,4 \pm 1,3$ & $2,5 \pm 0,2$ & $39,2 \pm 0,1$ & $6,9 \pm 1,2$ & $0,7 \pm 0,2$ & $103 \pm 17$ & $-1,5 \pm 0,2$ \\
\hline $\operatorname{ProD}_{3}+\mathrm{UV}$ & $39,4 \pm 0,1$ & $16,2 \pm 1,5$ & $3,4 \pm 0,2$ & $38,8 \pm 0,1$ & $8,2 \pm 1,0$ & $0,6 \pm 0,2$ & $71 \pm 11$ & $-2,0 \pm 0,2$ \\
\hline $\mathrm{VitD}_{3}$ & $38,8 \pm 0,1$ & $18,4 \pm 1,6$ & $5,5 \pm 0,2$ & $38,0 \pm 0,1$ & $8,4 \pm 1,2$ & $0,8 \pm 0,2$ & $38 \pm 5$ & $-2,6 \pm 0,2$ \\
\hline
\end{tabular}

It was established that among all the investigated samples $\mathrm{VitD}_{3}$ causes the lowest decrease in the temperature of the phase transition, equal to 2.6 and $2.8^{\circ} \mathrm{C}$ in the modes of heating and cooling, respectively, as well as the most expressed blurring of the peak on the DSC-thermogram.

Along with the observed "step-like" decrease in the temperature of the main phase transition of DPPCmembrane (upon introduction of $\mathrm{ProD}_{3}, \mathrm{UV}$-irradiation and subsequent dark storage of the sample) there is a remarkable increase in the half-width of the peak of the phase transition and a reduction in size of the cooperative domain. The most significant changes in these parameters were also observed upon the introduction of $\mathrm{VitD}_{3}$, for which the minimal value of the cooperative domain and the maximal value of the hysteresis were determined. There was no considerable difference in the effect of the additives in question on the enthalpy of melting the model membrane: all the additives in question reduces the enthalpy by approximately $30 \%$ (Table) within the experimental accuracy.

Therefore, the introduction of the additives allows registering a regular decrease in the melting temperature for the model lipid membrane in the sequence of $\operatorname{ProD}_{3}<\mathrm{ProD}_{3}+\mathrm{UV}<\mathrm{ProD}_{3}+\mathrm{UV}+$ dark storage $<\mathrm{VitD}_{3}$ (Table). Thus, during irradiation of the system containing $\mathrm{ProD}_{3}$ and its further dark storage the tendency is observed of shifting the melting peak to the values obtained for the systems containing VitD3.

A possible explanation of the observed regularity is presented below. The works [9, 18-19, 27, 29] allow us to assume that $\mathrm{ProD}_{3}$ and cholesterol have similar localization in the lipid membrane. ProD3 is predominantly located in the hydrophobic area of the lipid bilayer; its non-polar part interacts with the alkyl tails while $\mathrm{OH}$-group - with the carbonyl group of the lipid. By analogy with the structurally close cholesterol, $\mathrm{ProD}_{3}$ fills up the free space in the hydrophobic area of the bilayer, thus promoting the ordering of carbohydrate tails in the high temperature phase and its disordering in the low temperature phase, leading to the decrease in temperature and enthalpy of melting compared to the pure phospholipid matrix.

The observed tendency of further decrease in the melting temperature of the membrane containing ProD3 under UV-irradiation is related to the formation of the multicomponent mixture of photoisomers - previtamin, tachysterol, lumisterol and the primary ProD3. Their instability makes it impossible to determine the individual effect of each of them [3,4]. The isomers with the broken ring B (Fig. 1), so called secosteroids previtamin $\mathrm{D}_{3}$, tachysterol, VitD3 - have additional conformational flexibility. In particular, VitD3 may have "steroid" (cis-C6-C7) or "non-steroid", more protruded (trans-C6-C7) conformation [31]. Therefore, $\mathrm{UV}$-radiation in the system results in the formation of a set of isomers of different degrees of conformational flexibility and anisometry instead of one "rigid" $\operatorname{ProD}_{3}$. It leads to additional blurring of the transition peak and more notable decrease in Tm compared to the effect of $\operatorname{ProD}_{3}$.

Generally, it may be noted that the destabilizing impact of $\mathrm{VitD}_{3}$ on the membrane is considerably more expressed than that of ProD3 and the products of its photoisomerization. This is evident in larger decrease in the membrane melting temperature for $\mathrm{VitD}_{3}$ as compared to ProD3 (by -2.6 and $-1.5^{\circ} \mathrm{C}$, respectively) which is in good agreement with [the] current literature 


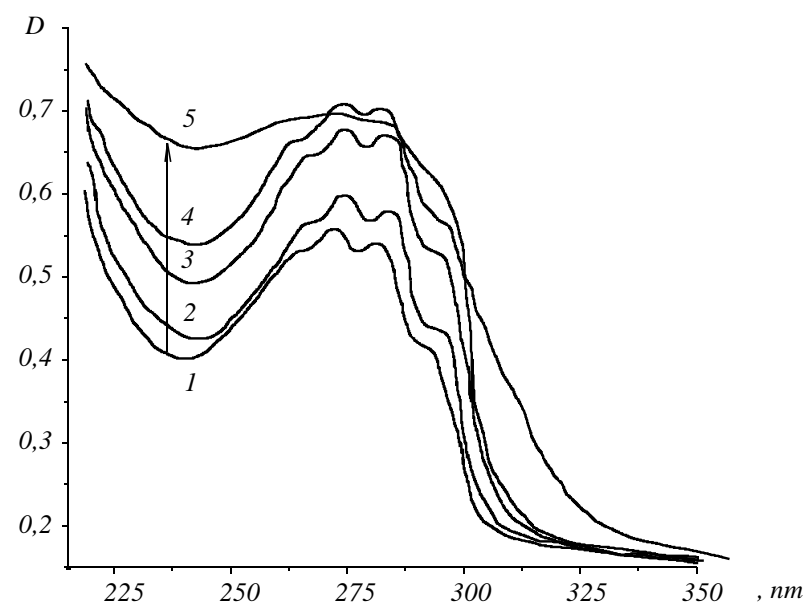

Fig. 3. The transformation of UV-spectrum of $\operatorname{ProD}_{3}$ absorption in the model lipid membrane: 1 - prior to irradiation; 2 - UV-irradiation for 5 $\min ; 3$ - for $10 \mathrm{~min} ; 4$ - for $15 \mathrm{~min} ; 5$ - subsequent dark storage

data on the lowering of the order parameter [20] and the increase in fluidity [21] of the membranes with VitD. From the standpoint of biochemistry it means that during the biosynthesis of $\mathrm{VitD}_{3}$ in vivo the local lipid medium of the sterol molecule is disordered (thinned) which facilitates the withdrawal of the formed $\mathrm{VitD}_{3}$ out of the membrane into the intracellular space.

Conclusions. The work demonstrates the regular decrease in the melting temperature of model lipid membranes on the basis of the hydrated DPPC doped with sterols in the sequence of $\operatorname{ProD}_{3}<\mathrm{ProD}_{3}+\mathrm{UV}<$ $\mathrm{ProD}_{3}+\mathrm{UV}+$ dark storage $<\mathrm{VitD}_{3}$. The probable molecular mechanism of a more expressed destabilizing impact of $\mathrm{VitD}_{3}$ on the membrane, compared to ProD3, is related to different degrees of conformational flexibility and anisometry of these molecules. The observed decrease in the membrane melting temperature during $\mathrm{VitD}_{3}$ biosynthesis may be one of the factors that ensure the withdrawal of $\mathrm{VitD}_{3}$ formed in vivo out of the membrane into the intracellular space.

\section{Н. А. Касян, О. В. Ващенко, Я. Э. Глухова ${ }^{\prime}$ Л. Н. Лисецкий}

Влияние продуктов фотосинтеза витамина D на

термодинамические параметры модельных липидных мембран

Институт сцинтилляционных материалов НТК «Институт монокристаллов» НАН Украины

Пр. Ленина, 60, Харьков, Украина, 61001
${ }^{1}$ Харьковский национальный университет им. В. Н. Каразина Пл. Свободы, 4, Харьков, Украина, 61077

Summary

Цель. Сравнить влияние провитамина D (ProD) и продуктов его фото- и термоизомеризации, а также витамина D (VitD) на термодинамические параметры мультислоев гидратированного дипальмитоилфосфатидилхолина (ДПФХ). Методы. Дифференциальная сканирующая калориметрия, УФ-спектроскопия. Результаты. Установлено закономерное снижение температуры и размывание пика плавления мультислоев ДПФХ, допированных стеринами, в последовательности $\mathrm{ProD}_{3}<$ $\operatorname{ProD}_{3}+$ УФ $<\mathrm{ProD}_{3}++$ УФ + темновое хранение $<$ VitD $D_{3}$ Выводы. Дестабилизирующее действие $V_{i t} D_{3}$ на мембрану является более выраженным, чем действие $\mathrm{ProD}_{3}$ и продуктов его фотои-

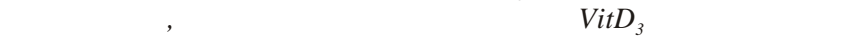
межклеточное пространство при его биосинтезе in vivo. Возможный молекулярный механизм наблюдаемого явления связан $c$ большей конформационной подвижностью и анизо- метрией $\mathrm{Vit}_{3}$ по сравнению с $\mathrm{ProD}_{3}$.

Ключевые слова: фосфолипидные мембраны, витамин $D$, провитамин D, фотоизомеризация, дифференциальная сканирующая калориметрияН. О. Касян, О. В. Ващенко, Я. Е. Глухова, Л. М. Лисещький

Вплив продуктів фотосинтезу вітаміну D на термодинамічні параметри модельних ліпідних мембран

Резюме

Мета. Порівняти вплив провітаміну D (ProD) та продуктів його фото- і термоізомеризації, а також вітаміну D (VitD) на термодинамічні параметри мультишарів гідратованого дипальмітоїлфосфатидилхоліну (ДПФХ). Методи. Диференційна сканувальна калориметрія, УФ-спектроскопія. Результати. Встановлено закономірне зниження температури та розмивання піка плавлення мультишарів ДПФХ, допованих стеринами, у послідовності $\operatorname{ProD}_{3}<\mathrm{ProD}_{3}+$ УФ $<$ ProD $_{3}+$ УФ + темнове зберігання $<$ VitD . Висновки. Дестабілізувальний вплив VitD ${ }_{3}$ на мембрану є більш вираженим, ніж ProD $_{3}$ та продуктів його фотоізомеризації, що полегшуе вихід $V_{i t D_{3}}$ із мембрани у міжклітинний простір за його біосинтезу in vivo. Можливий молекулярний механізм спостереженого явища пов'язаний з більш високою конформаційною рухливістю та анізометрією VitD nорівняно $_{3} \operatorname{ProD}_{3}$.

Ключові слова: фосфоліпідні мембрани, вітамін D, провітамін $D$, фотоізомеризація, диференційна сканувальна калориметрія.

\section{REFERENCES}

1. Holick M. F., McLaughlin J. A., Clark M. B., Holick S. A., Potts J. T., Anderson R. R., Blank I. H., Parrish J. A., Elias P. Photosynthesis of previtamin $\mathrm{D}_{3}$ in human skin and the physiologic consequences // Science.-1980.-210, N 4466.-P. 203-205.

2. Verloop A., Koevoet A. L., Havinga E. Studies on vitamin D and related compounds III. Short communications on the cis-transisomerization of calciferol and properties of «trans»-vitamin $\mathrm{D}_{2}$ // Rec. Trav. Chim.-1955.-74, N 9.-P. 1125-1130.

3. Jacobs H. J. C., Havinga E. Photochemistry of Vitamin D and its isomers and of simple trienes // Adv. Photochem.-1979-11.P. 305-373.

4. Yakhimovich R. I. Chemistry of vitamins D.-Kyiv: Naukova dumka, 1978.-248 p. 
5. Werner F., Lochbrunner S. The wavelength dependence of the photochemistry of previtamin D // J. Photochem. Photobiol. A: Chem.-1997.-105, N 2-3.-P. 159-164.

6. Dmitrenko O. F., Frederick J. H., Reischl W. Previtamin D conformations and the wavelength-dependent photoconversions of previtamin D // J. Photochem. Photobiol. A: Chem.-2001.-139, N 2.-P. 125-131.

7. Terenetskaya I. P., Vysotskiy L. H., Bogoslovskiy N. A., Luknitskiy $F$. I. The ways of previtamin D photosynthesis optimization under irradiation with erythema lamp // Khim. Pharm. Zhur.1993.-27, N 4.-P. 55-59.

8. MacLaughlin J. A., Anderson R. R., Holick M. F. Spectral character of sunlight modulates photosynthesis of provitamin $\mathrm{D}_{3}$ and its photoisomers in human skin // Science.-1982.-216, N 4549.-P. 1001-1003.

9. Tian X. Q., Holick M. F. A liposomal model that mimics the cutaneous production of vitamin $\mathrm{D}_{3}$. Studies of the mechanism of the membrane-enhanced thermal isomerization of previtamin $\mathrm{D}_{3}$ to vitamin $\mathrm{D}_{3} / /$ J. Biol. Chem.-1999.-274, N 7.-P. 4174-4179.

10. Moriarty R. M., Schwartz R. N., Lee C., Curtis V. Formation of vitamin $\mathrm{D}_{3}$ in synthetiic lipid multibilayers. A model for epidermal photosynthesis // J. Am. Chem. Soc.-1980.-102, N 12.P. 4257-4259.

11. Yamamoto J. K., Borch R. F. Photoconversion of 7-dehydrocholesterol to vitamin $\mathrm{D}_{3}$ in synthetic phospholipid bilayers // Biochemistry.-1985.-24, N 13.-P. 3338-3344.

12. Holick M. F., Tian X. Q., Allen M. Evolutionary importance for the membrane enhancement of the production of vitamin $\mathrm{D}_{3}$ in the skin of poikilothermic animals // Proc. Natl Acad. Sci. USA.1995.-92, N 8.-P. 3124-3126.

13. Tian X. Q., Chen T. Ch., Matsuoka L. Y., Wortsman J., Holick M. $F$. Kinetic and thermodynamic studies of the conversion of provitamin $\mathrm{D}_{3}$ to vitamin $\mathrm{D}_{3}$ in human skin // J. Biol. Chem.-1993.268, N 20.-P. 14888-14892.

14. Cassis E. G. Jr., Weiss R. G. Liquid-crystalline solvents as mechanistic probes $-V$. An investigation of the effect of cholesteric order on the formation rates of vitamin $\mathrm{D}_{3}$ from pre-vitamin $\mathrm{D}_{3}$ and of the pre-vitamin $\mathrm{D}_{3}$ from vitamin $\mathrm{D}_{3} / /$ Photochem. Photobiol.-1982.-35, N 4.- P. 439-444.

15. Gvozdovsky I. A., Terenetskaya I. P. Comparative study of the provitamin $D$ photoisomerization kinetics in ethanol and liquid crystal // Functional Materials.-2000.-7, N 3.-P. 508-512.

16. Terenetskaya I. P., Dmitrenko O. G., Eremenko A. M. Photoisomerization of provitamin D in dispersive systems // J. Mol. Struct.1990.-219, N 1-2.-P. 359-364.

17. Tian X. Q., Holick M. F. Catalyzed thermal isomerization between provitamin $D_{3}$ and vitamin $D_{3}$ via beta-cyclodextrin complexation // J. Biol. Chem.-1995.-270, N 15.-P. 8706-8711.

18. Cournia Z., Ullmann G. M., Smith J. C. Differential effects of cholesterol, ergosterol and lanosterol on dipalmitoyl phosphati- dylcholine membrane: a molecular dynamics simulation study // J. Phys. Chem. B.-2007.-111, N 7.-P. 1786-1801.

19. Kazanci N., Toyran N., Haris P. I., Severcan F. Vitamin $\mathrm{D}_{2}$ at high and low concentrations exert opposing effects on molecular order and dynamics of dipalmitoyl phosphatidylcholine membranes // Spectroscopy.-2001.-15, N 2.-P. 47-55.

20. Tolosa de Talamoni N., Morero R., Canas F. Vitamin $\mathrm{D}_{3}$ administration increases the membrane fluidity of intestinal mitochondria // Biochem. Int.-1989.-19, N 4 .-P. 701-707.

21. Castelli F., Gurrieri S., Raudino A., Cambria A. Effect of cholecalcipherol on thermotropic behaviour of phosphatidylethanolamine and its N-methyl derivatives // Chem. Phys. Lipids.1988.-4, N 1-2.-P. 69-76.

22. Toyran N., Severcan F. Competitive effect of vitamin $\mathrm{D}_{2}$ and $\mathrm{Ca}^{2+}$ on phospholipid model membranes: an FTIR study // Chem. Phys. Lipids.-2003.-123, N2.-P. 165-176.

23. Toyran N., Severcan F. The effect of magnesium ions on vitamin $\mathrm{D}(2)$-phospholipid model membrane interactions in the presence of different buffer media // Talanta.-2000.-53, N 1.P. 23-27.

24. Eker F., Durmus H. O., Akinoglu B. G., Severcan F. Application of turbidity technique on peptide-lipid and drug-lipid interactions // J. Mol. Struct.-1999.-482-483, N 1-3.-P. 693-697.

25. Bondar O. P., Rowe E. S. Differential scanning calorimetric study of the effect of vitamin $\mathrm{D}_{3}$ on the thermotropic phase behaviour of lipid model systems // Biochim. Biophys. Acta.-1995.1240, N 2.-P. 125-132.

26. Merz K., Sternberg B. Incorporation of vitamin $\mathrm{D}_{3}$-derivatives in liposomes of different lipid types // J. Drug Target.-1994.-2, N 5.-P. 411-417.

27. Ivkov V. G., Berestovskiy G. N. Dynamic structure of lipid bilayer.-Moscow: Nauka, 1981.-296 p.

28. Wack D. C., Webb W. W. Synchrotron X-ray study of the modulated lamellar phase $\mathrm{P}_{\beta}$, in the lecithin-water system // Phys. Rev. A.-1989.-40, N 5.-P. 2712-2730.

29. Antonov V. F., Smirnova E. Y., Shevchenko E. V. Lipid membranes under phase transformations.-Moscow: Nauka, 1992.- $135 \mathrm{p}$.

30. Lisetski L. N., Panikarskaya V. D., Kasyan N. A., Grishchenko $L$. V., Terenetskaya I. P. Bioequivalent UV detectors based on cholesteric liquid crystals: effects of spectral composition and quantitative account for intensity of UV radiation // Proc. SPIE.- 2005.-6023, 6023OF1.-4 p.

31. Okamura W. H., Midland M. M., Hammond M. W., Rahman N. Abd., Dormanen M. C., Nemere I., Norman A. W. Chemistry and conformation of vitamin D molecules // J. Steroid Biochem. Mol. Biol.-1995.-53, N 1-6.-P. 603-613. 